\title{
Some physical properties of sweet cherries
}

\author{
Polyák, N. I., Csizmazia, Z. \& Ancza, E. \\ Center of Agricultural Sciences and Engineering, University of Debrecen, 138 Böszörményi St., \\ 4032 Debrecen, Hungary
}

\begin{abstract}
Summary: The determination of the optimal time of the mechanical harvesting of sweet cherries has a great importance not only to prevent the fruit from mechanical injury but to find the optimal setting parameters of the harvesting machine. The primary objective of the experiments was to determine the force and work required to detach the stem from the limb and the fruit from the stem. Furthermore to measure the three main sizes (width, height, thickness) of the fruits in order to determine the sphericity, and also the pulp-stone ratio by measuring the mass of the fruit with the stone and then the mass of the stone. The average sizes of the fruits: width 19.62-27.76 mm, height $17.83-24.54 \mathrm{~mm}$ and thickness $17.30-23.60 \mathrm{~mm}$. The stem length varied between $28.69 \mathrm{~mm}$ and $55.80 \mathrm{~mm}$. The sphericity of each variety was above $90 \%$. The average mass varied between 3.63 and $9.68 \mathrm{~g}$. The stone mass turned to be between $0.27 \mathrm{~g}$ and $0.42 \mathrm{~g}$. The stone-pulp ratio varied between $3.7 \%$ and $7.7 \%$. The average pulp mass varied between $3.35 \mathrm{~g}$ and $9.32 \mathrm{~g}$. The average values of maximum loads required to detach the sweet cherries from the stem varied between $3.23 \mathrm{~N}$ and, $4.12 \mathrm{~N}$. The force required to detach the stem from the limb was 50-90\% higher than the force needed to tear the fruit from the stem.
\end{abstract}

Key words: fruit harvesting, fruit detachment, physical properties

\section{Introduction}

The determination of the optimal time of the mechanical harvesting of sweet cherries has a great importance not only to prevent the fruit from mechanical injury but to find the optimal setting parameters of the harvesting machine. In this respect the knowledge of the force and work required to detach the stem from the limb and the fruit from the stem is essential. The task is to remove the fruit from the stem without breaking the stem from the limb.

Harvesting at the optimal time and performing it with the optimal operational parameters (frequency and displacement) mean less damage to the fruit and more efficiency.

The knowledge of some further physical properties (size, shape and mass) is important from other points of view, such as fruit quality, material handling and manipulating. According to Soltész (1998) the quality of fruit is influenced by its physical appearance. Papp (2003) says that the physical appearance of fruit has to be considered when describing its quality. He believes that the aim is to grow fruits of 10-11 $\mathrm{g}$ in discrete mass. However, the utilization of the appropriate technological elements can result in producing fruits heavier than 11g (Hrotkó 2003). According to Papp (2003) customers find the visual quality of fruit sometimes more important than the internal quality. Polyák \& Csizmazia (2003) analysed the physical properties (size, shape, mass and sphericity) of vegetable seeds. The typical diameter, width, height, single mass and stone mass were investigated in the case of 8 varieties of sweet cherries by Thurzó et al. (2005ab). They contrasted their results with the $26 \mathrm{~mm}$ diameter required on the world market. They found that from the investigated varieties only 2 (Vera and Margit) fulfilled the above mentioned requirement and 2 other types (Germersdorfi and Van) neared it. The stone-pulp ratio was emphasised as being a determinative feature considering the quality of fruit.

The conditions of mechanical harvesting of fruits were studied by several Hungarian and foreign researchers. Lenker \& Hedden (1968) investigated the optimal operational characteristics of tree shakers. Cooke \& Rand (1969) worked out the linear, Rand \& Cook (1970) the non-linear theory of vibratory fruit harvesting relating to fruit-stem system dynamics. Horváth \& Sitkei (2001) introduced a model to determine the energy consumption of trunk shakers. Mateev \& Kostadinov (2004) worked out the probabilistic model of fruit removal during vibratory morello harvesting. Fekete et al. (2005) made a detailed study of the kinematics and dynamic systems of shaking machines.

The primary objective of the experiments was to determine the force and work required to detach the stem from the limb and the fruit from the stem. Furthermore to measure the three main sizes (width, height, thickness) of the fruits in order to determine the sphericity, and also the stonepulp ratio by measuring the mass of the fruit with the stone and then the mass of the stone. 


\section{Materials and methods}

The following varieties of sweet cherries were investigated: Vega, Axel, Linda, Blaze Star, Stella, Cristalline, Katalin, Germersdorfi, and Sunburst. All these cultivars come from the same site, the Experimental Orchard of Centre of Agricultural Sciences and Engineering, University of Debrecen, in Pallag. The sampling was performed always in the morning (approx. $8 \mathrm{am}$ ) from different orientation of the selected trees, from different heights of crowns. The samples were immediately taken to the material testing laboratory of the Department of Agricultural Machinery, Institute for Land Utilization, Technology and Regional Development, Faculty of Agricultural Science, University of Debrecen, so the measurements were always carried out with fresh fruits.

In most cases (5 varieties) there were four sampling times, in two cases there were five, and in one case three. In the case of Blaze Star the behaviour of the overripe fruit was studied, so in this case was only one sampling time.

The sampling data of the different varieties is shown in Table 1.

Keeping the rules of sampling, 25-25 sweet cherries were selected from each sample. A digital slide gauge with an accuracy of $0,01 \mathrm{~mm}$ was used to measure the sizes. The length of the stem was also measured so that the force and work acting during the shaking could be modelled and determined.

The mass of each sweet cherry was measured by an analytical balance, with an accuracy of $0,1 \mathrm{mg}$. After removing the stone it was carefully cleaned and measured, too. Knowing the mass of fruit and stone we could calculate the stone-pulp ratio, and also the net pulp mass.

A Lloyd Instruments LRX, UK, material testing machine was used to measure the tensile force. The clamping apparatus of the instrument was modified to be suitable for sweet cherries (Figure 1.)

Although the machine can be equipped with a selection of specially engineered grips, as well as a range of multipurpose grips for more general applications, we had to modify this part of the machine, because in the case of some varieties the length of the stem was shorter than the vertical size (height) of the clamp jaw of the grip. To perform a test

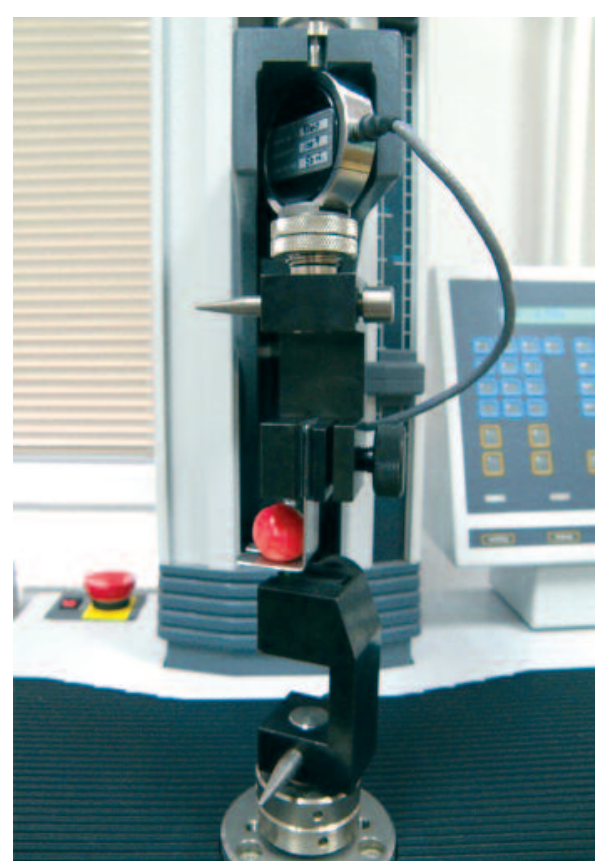

Figure 1. The modified grip

the sweet cherry has to be placed onto the holder of the grip while its stem is fixed into the lower clamp jaw.

A load cell of $50 \mathrm{~N}$ was used which has the necessary sensitivity in the range of $0-10 \mathrm{~N}$.

A specimen was prepared to tear the stem from the limb and when the fruits were grouped on a limb, more stems were tore from one limb to measure the tensile force.

The testing procedure itself involves pulling the stem or the specimen with a controlled, gradually increasing force until it breaks.

The measuring data were recorded by the NEXYGENTM MT material test and data analysis software, which provided the breaking force-time graph.

The data recorded by the NEXYGENTM MT software were exported then into an Excel file for further analysis.

The measured size and mass data were also processed by Excel spreadsheet program.

\section{Results and discussion}

\section{Size, size distribution, sphericity}

The measuring data are given in Table 2 According to our results the average sizes of the fruits are the next: width 19,62-27,76 mm, height 17,83-24,54 $\mathrm{mm}$ and thickness 17,30-23,60 mm. Considering all three sizes Blaze Star proved to be the smallest and Germersdorfi the largest. The desired diameter of $26 \mathrm{~mm}$ (i.e. width) was reached, as an average, by Cristallina, Germersdorfi, Linda and Vega (Figure 2). The stem length varied between 28,69 $\mathrm{mm}$ and 55,80 $\mathrm{mm}$. The lowest 
Table 2. Some physical properties of the examined sweet cherry varieties

\begin{tabular}{|c|c|c|c|c|c|c|}
\hline \multicolumn{2}{|l|}{ Variety } & $\begin{array}{l}\text { Width } \\
{[\mathrm{mm}]}\end{array}$ & $\begin{array}{l}\text { Height } \\
{[\mathrm{mm}]}\end{array}$ & $\begin{array}{c}\text { Thickness } \\
\text { [mm] }\end{array}$ & $\begin{array}{c}\text { Length of stem } \\
{[\mathrm{mm}]}\end{array}$ & Sphericity \\
\hline \multirow{4}{*}{ Axel } & Mean & 23.35 & 22.35 & 20.31 & 28.69 & 0.941 \\
\hline & Std. dev. & 1.97 & 1.72 & 1.47 & 2.86 & 0.015 \\
\hline & Min. & 19.89 & 19.63 & 17.12 & 23.99 & 0.910 \\
\hline & Max. & 26.58 & 25.71 & 23.56 & 37.06 & 0.965 \\
\hline \multirow{4}{*}{ Blaze Star } & Mean & 19.62 & 17.83 & $\mathbf{1 7 . 3 0}$ & 33.33 & 0.929 \\
\hline & Std. dev. & 1.21 & 0.83 & 0.86 & 2.77 & 0.017 \\
\hline & Min. & 17.91 & 16.34 & 16.03 & 29.65 & 0.898 \\
\hline & Max. & 22.56 & 19.50 & 19.17 & 39.10 & 0.967 \\
\hline \multirow{4}{*}{ Cristallina } & Mean & 27.00 & 24.44 & 21.38 & 41.74 & 0.895 \\
\hline & Std. dev. & 1.48 & 0.70 & 0.64 & 27.75 & 0.000 \\
\hline & Min. & 24.73 & 22.46 & 19.76 & 28.78 & 0.864 \\
\hline & Max. & 29.88 & 25.54 & 22.59 & 52.68 & 0.929 \\
\hline \multirow{4}{*}{ Germersdorfi } & Mean & 27.76 & 24.52 & 23.60 & 48.74 & 0.909 \\
\hline & Std. dev. & 1.15 & 0.88 & 1.09 & 3.10 & 0.014 \\
\hline & Min. & 26.08 & 22.74 & 21.31 & 42.51 & 0.885 \\
\hline & Max. & 31.02 & 26.19 & 25.83 & 54.67 & 0.940 \\
\hline \multirow{4}{*}{ Katalin } & Mean & 25.45 & 23.61 & 21.56 & 55.80 & 0.923 \\
\hline & Std. dev. & 1.87 & 1.62 & 1.38 & 5.39 & 0.015 \\
\hline & Min. & 22.47 & 21.29 & 19.19 & 45.15 & 0.897 \\
\hline & Max. & 29.21 & 26.65 & 24.01 & 66.17 & 0.952 \\
\hline \multirow{4}{*}{ Linda } & Mean & 27.16 & 24.01 & 22.16 & 48.83 & 0.897 \\
\hline & Std. dev. & 1.43 & 0.93 & 1.36 & 6.04 & 0.020 \\
\hline & Min. & 22.89 & 21.88 & 17.65 & 34.59 & 0.859 \\
\hline & Max. & 29.37 & 25.54 & 23.92 & 59.32 & 0.952 \\
\hline \multirow{4}{*}{ Stella } & Mean & 23.37 & 23.88 & 20.29 & 41.81 & 0.938 \\
\hline & Std. dev. & 1.11 & 0.87 & 0.74 & 3.88 & 0.011 \\
\hline & Min. & 19.67 & 21.19 & 18.55 & 31.34 & 0.915 \\
\hline & Max. & 26.27 & 25.29 & 21.41 & 49.34 & 0.954 \\
\hline \multirow{4}{*}{ Sunburst } & Mean & 24.77 & 22.62 & 21.41 & 39.75 & 0.924 \\
\hline & Std. dev. & 1.17 & 0.96 & 1.02 & 6.44 & 0.011 \\
\hline & Min. & 22.05 & 19.93 & 19.58 & 25.62 & 0.901 \\
\hline & Max. & 26.81 & 24.47 & 22.96 & 52.39 & 0.944 \\
\hline \multirow{4}{*}{ Vega } & Mean & 27.37 & 24.21 & 22.91 & 34.06 & 0.905 \\
\hline & Std. dev. & 1.81 & 1.18 & 1.58 & 5.70 & 0.015 \\
\hline & Min. & 22.29 & 21.94 & 18.68 & 23.15 & 0.869 \\
\hline & Max. & 30.59 & 25.95 & 25.24 & 46.13 & 0.938 \\
\hline
\end{tabular}

Measuring data

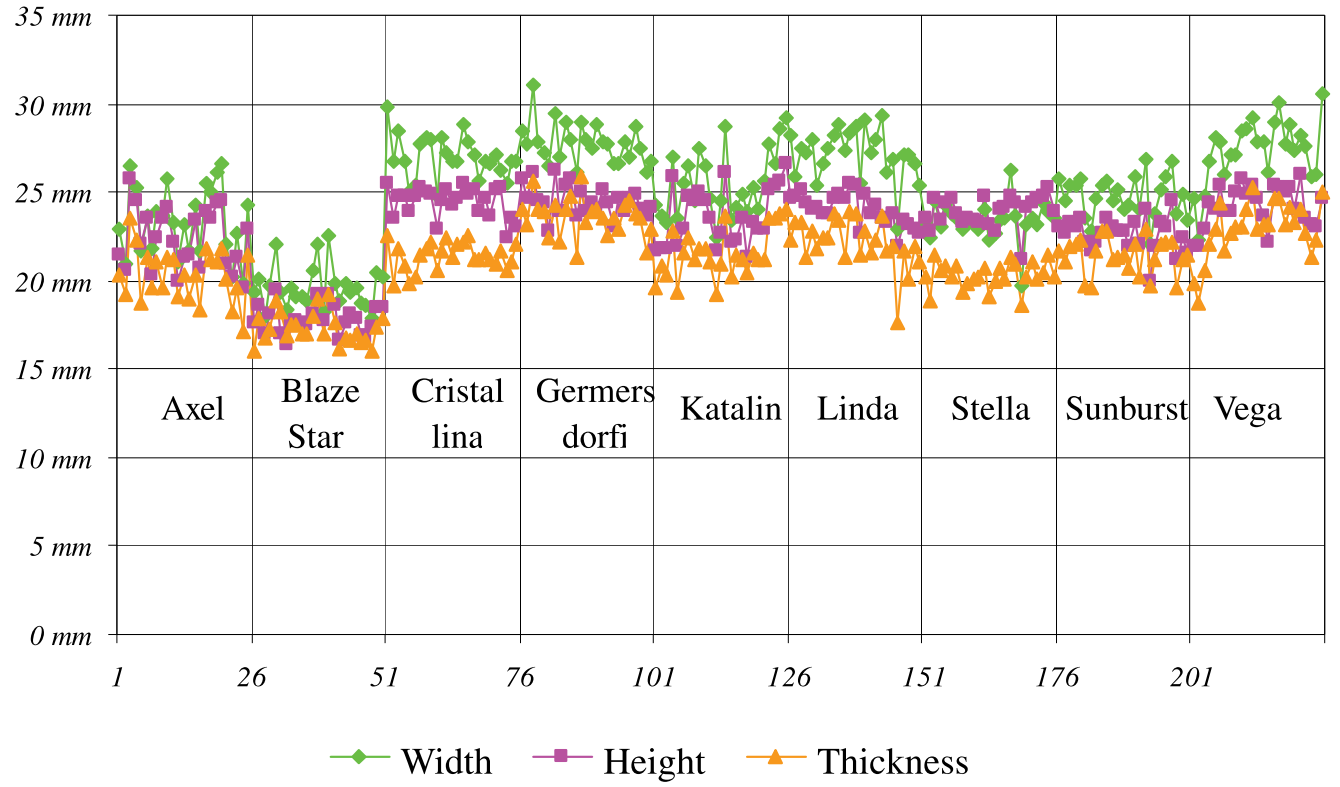

Figure 2. The average values of the three sizes of the investigated sweet cherry varieties 


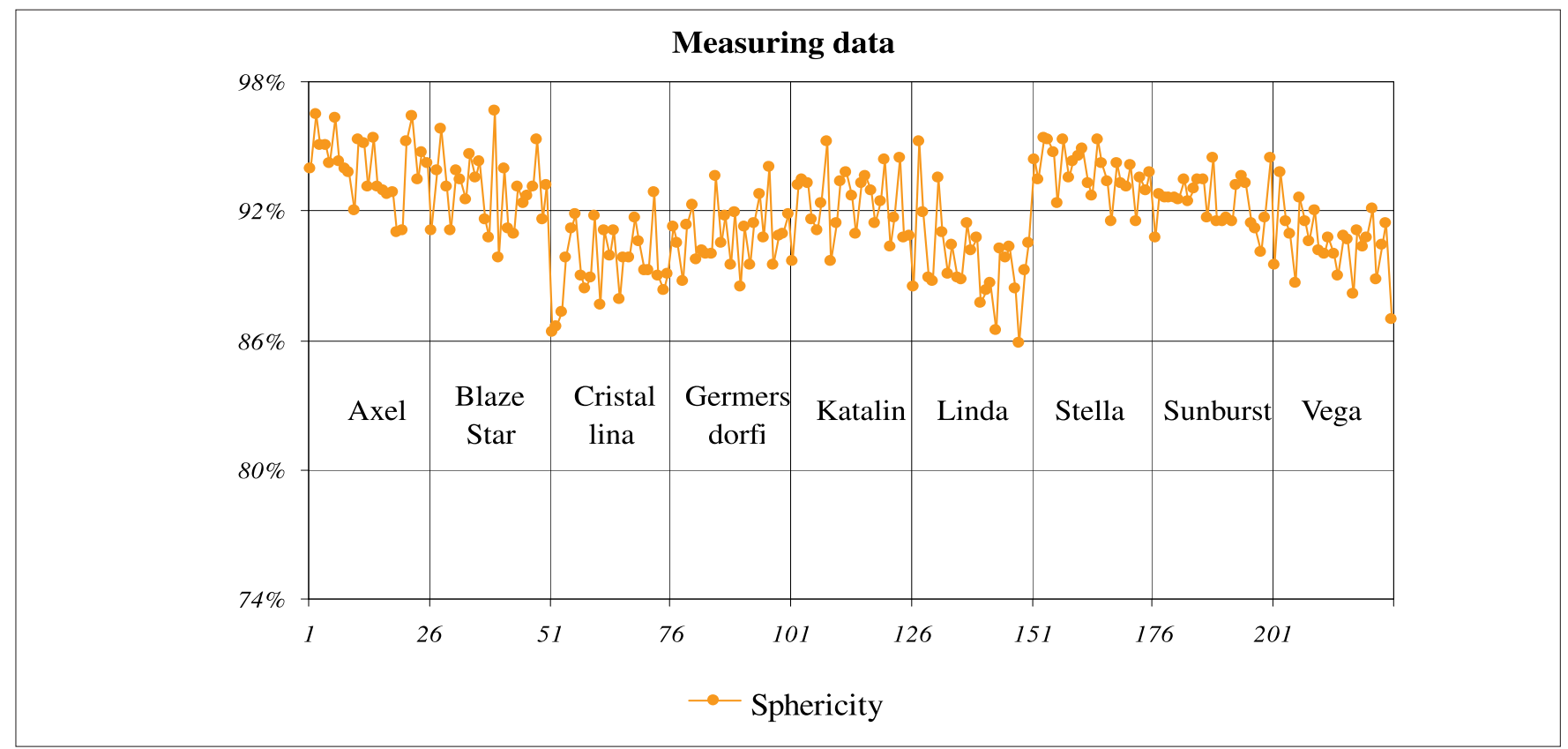

Figure 3. The sphericity of the examined varieties

value was measured with Axel, and the highest with Katalin. The sphericity of each variety was above $90 \%$. The lowest value (90\%) was measured with Cristallina, and Linda, and the highest (94\%) with Axel (Figure 3.). This value is important considering the visual quality, the market value and also the mechanization of sorting processes.

\section{Mass of fruit, mass of stone, mass of pulp}

The measuring data are given in Table 3 The average mass of the investigated varieties varied between 3,63 (Blaze Star) and 9,68 g (Germersdorfi). The stone mass turned to be between 0,27 $\mathrm{g}$ and 0,42 $\mathrm{g}$, with the smallest value of Axel, and the largest of Germersdorfi. Regarding the stone-pulp ratio Vega proved to be the most favourable, with a 3,7\% value, and Blaze Star the most unfavourable with a $7,7 \%$ average value. In the case of the other varieties the stone-pulp ratio was 4-5\% (Figure 4.). The average pulp mass varied between 3,35 $\mathrm{g}$ (Blaze Star) and 9,32 g (Vega).

\section{Load at break and work to break}

The average values of maximum loads required to detach the sweet cherries from the stem and the work required to

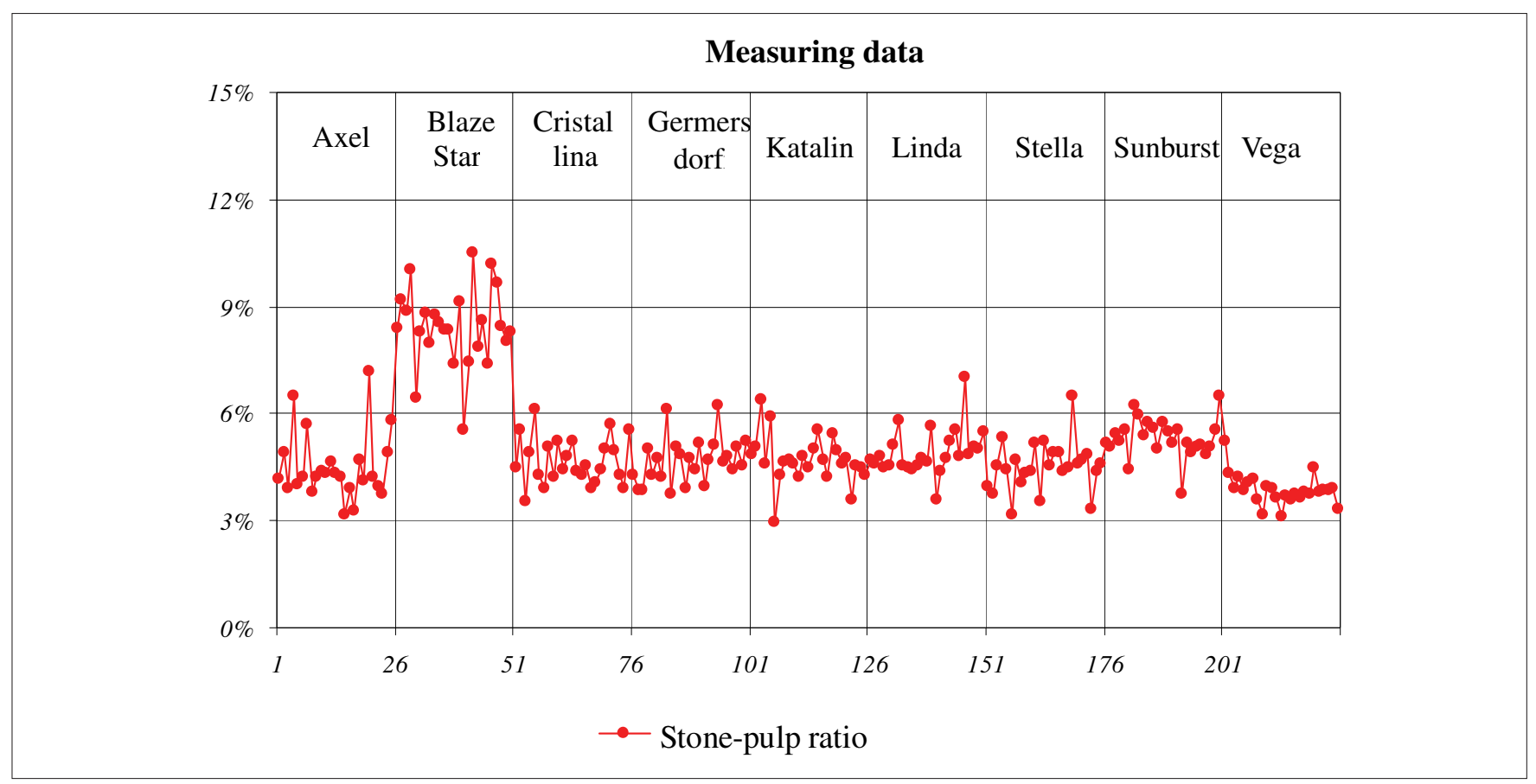

Figure 4. The stone-pulp ratio of the investigated varieties 
Table 3. Some physical properties of the examined sweet cherry varieties

\begin{tabular}{|c|c|c|c|c|c|c|}
\hline \multicolumn{2}{|l|}{ Variety } & $\begin{array}{l}\text { Width } \\
{[\mathrm{mm}]}\end{array}$ & $\begin{array}{c}\text { Height } \\
{[\mathrm{mm}]}\end{array}$ & $\begin{array}{l}\text { Thickness } \\
\text { [mm] }\end{array}$ & $\begin{array}{c}\text { Length of stem } \\
{[\mathrm{mm}]}\end{array}$ & Sphericity \\
\hline \multirow{4}{*}{ Axel } & Mean & 23.35 & 22.35 & 20.31 & 28.69 & 0.941 \\
\hline & Std. dev. & 1.97 & 1.72 & 1.47 & 2.86 & 0.015 \\
\hline & Min. & 19.89 & 19.63 & 17.12 & 23.99 & 0.910 \\
\hline & Max. & 26.58 & 25.71 & 23.56 & 37.06 & 0.965 \\
\hline \multirow{4}{*}{ Blaze Star } & Mean & 19.62 & 17.83 & 17.30 & 33.33 & 0.929 \\
\hline & Std. dev. & 1.21 & 0.83 & 0.86 & 2.77 & 0.017 \\
\hline & Min. & 17.91 & 16.34 & 16.03 & 29.65 & 0.898 \\
\hline & Max. & 22.56 & 19.50 & 19.17 & 39.10 & 0.967 \\
\hline \multirow{4}{*}{ Cristallina } & Mean & 27.00 & 24.44 & 21.38 & 41.74 & 0.895 \\
\hline & Std. dev. & 1.48 & 0.70 & 0.64 & 27.75 & 0.000 \\
\hline & Min. & 24.73 & 22.46 & 19.76 & 28.78 & 0.864 \\
\hline & Max. & 29.88 & 25.54 & 22.59 & 52.68 & 0.929 \\
\hline \multirow{4}{*}{ Germersdorfi } & Mean & 27.76 & 24.52 & 23.60 & 48.74 & 0.909 \\
\hline & Std. dev. & 1.15 & 0.88 & 1.09 & 3.10 & 0.014 \\
\hline & Min. & 26.08 & 22.74 & 21.31 & 42.51 & 0.885 \\
\hline & Max. & 31.02 & 26.19 & 25.83 & 54.67 & 0.940 \\
\hline \multirow{4}{*}{ Katalin } & Mean & 25.45 & 23.61 & 21.56 & 55.80 & 0.923 \\
\hline & Std. dev. & 1.87 & 1.62 & 1.38 & 5.39 & 0.015 \\
\hline & Min. & 22.47 & 21.29 & 19.19 & 45.15 & 0.897 \\
\hline & Max. & 29.21 & 26.65 & 24.01 & 66.17 & 0.952 \\
\hline \multirow{4}{*}{ Linda } & Mean & 27.16 & 24.01 & 22.16 & 48.83 & 0.897 \\
\hline & Std. dev. & 1.43 & 0.93 & 1.36 & 6.04 & 0.020 \\
\hline & Min. & 22.89 & 21.88 & 17.65 & 34.59 & 0.859 \\
\hline & Max. & 29.37 & 25.54 & 23.92 & 59.32 & 0.952 \\
\hline \multirow{4}{*}{ Stella } & Mean & 23.37 & 23.88 & 20.29 & 41.81 & 0.938 \\
\hline & Std. dev. & 1.11 & 0.87 & 0.74 & 3.88 & 0.011 \\
\hline & Min. & 19.67 & 21.19 & 18.55 & 31.34 & 0.915 \\
\hline & Max. & 26.27 & 25.29 & 21.41 & 49.34 & 0.954 \\
\hline \multirow{4}{*}{ Sunburst } & Mean & 24.77 & 22.62 & 21.41 & 39.75 & 0.924 \\
\hline & Std. dev. & 1.17 & 0.96 & 1.02 & 6.44 & 0.011 \\
\hline & Min. & 22.05 & 19.93 & 19.58 & 25.62 & 0.901 \\
\hline & Max. & 26.81 & 24.47 & 22.96 & 52.39 & 0.944 \\
\hline \multirow{4}{*}{ Vega } & Mean & 27.37 & 24.21 & 22.91 & 34.06 & 0.905 \\
\hline & Std. dev. & 1.81 & 1.18 & 1.58 & 5.70 & 0.015 \\
\hline & Min. & 22.29 & 21.94 & 18.68 & 23.15 & 0.869 \\
\hline & Max. & 30.59 & 25.95 & 25.24 & 46.13 & 0.938 \\
\hline
\end{tabular}

that are shown in Table 4. The load necessary to remove the sweet cherries from the stem and proportionally the work done during that gradually decreased with the time, i.e. with ripening (aside from some exceptions). In the case of Axel the largest force was $6,87 \mathrm{~N}$, which decreased continually in the following five periods, and the lowest average breaking force $(3,79 \mathrm{~N})$ was obtained at the fifth time. Only one measurement series was carried out with the overripe Blaze Star, and the average tensile force was 3,52 N. The highest value for the breaking force obtained with Cristallina was $6,72 \mathrm{~N}$ which fell to $3,65 \mathrm{~N}$ for the third date. The maximal tensile force obtained with Germersdorfi was 5,52 N, and it dropped to $3,82 \mathrm{~N}$ on the third occasion. On the fourth date there was a slight increase. In the case of Katalin we measured an extremely high breaking force, 16,27 $\mathrm{N}$ for the first time; however with this variety the measurements were started relatively early regarding the ripeness date. The minimal force $(3,98 \mathrm{~N})$ was obtained for the third time, and it increased slightly for the following times. Analysing the results of Linda sweet cherry, the largest tensile force was 5,9 $\mathrm{N}$ which decreased gradually to 3,69 $\mathrm{N}$. The same results for Stella were 6,23N and 3,23 N, in which case the decrease was also gradual. The sampling date was relatively early considering the ripeness date of Sunburst, which can be an explanation for the large breaking force $(10,93 \mathrm{~N})$ that then decreased gradually and reached a value of $4,12 \mathrm{~N}$ for the fourth time. In the case of Vega the largest force was 4,87 N, which fell to $3,69 \mathrm{~N}$ next time and started to increase for the following occasions. The work to break varied proportionally with the maximal tensile forces (Table 5). The changes in maximal load and work to break in the function of time are shown in the case of Linda sweet cherry on Figure 5.

The force required to detach the stem from the limb with some varieties was also measured.

We found that this force is 50-90\% higher than the force needed to tear the fruit from the stem.

On the basis of these results the optimal harvesting date can be appointed and the shaking parameters can be adjusted properly, and so the efficiency of detachment will increase.

Knowing the mass and the stem length of the individual fruits the force acting on them and the work done during the shaking can be calculated. The operational parameters of the shaking machine can be checked by a calculation with the measured data. 
Table 4. The values of maximum load

\begin{tabular}{|c|c|c|c|c|c|c|}
\hline \multirow{2}{*}{ Variety } & \multirow[b]{2}{*}{ Date } & \multicolumn{5}{|c|}{ Maximum Load [N] } \\
\hline & & 2009.06 .05 & 2009.06.11 & 2009.06.16 & 2009.06 .22 & 2009.06 .30 \\
\hline \multirow{4}{*}{ Axel } & Mean & 6,87 & 5,09 & 4,64 & 4,53 & 3,79 \\
\hline & Std. dev. & 0,86 & 0,76 & 0,74 & 0,91 & 0,81 \\
\hline & Min. & 5,57 & 3,73 & 2,28 & 1,77 & 2,17 \\
\hline & Max. & 8,79 & 6,31 & 5,52 & 6,40 & 5,99 \\
\hline \multirow{4}{*}{ Blaze Star } & Mean & 3,52 & & & & \\
\hline & Std. dev. & 0,92 & & & & \\
\hline & Min. & 1,86 & & & & \\
\hline & Max. & 5,16 & & & & \\
\hline \multirow{4}{*}{ Cristallina } & Mean & 6,72 & 4,72 & 3,65 & & \\
\hline & Std. dev. & 0,92 & 1,06 & 0,90 & & \\
\hline & Min. & 5,39 & 2,87 & 1,46 & & \\
\hline & Max. & 8,99 & 7,13 & 6,38 & & \\
\hline \multirow{4}{*}{ Germersdorfi } & Mean & 5,52 & 4,79 & 3,82 & 4,14 & \\
\hline & Std. dev. & 1,42 & 0,78 & 0,76 & 0,86 & \\
\hline & Min. & 3,50 & 3,07 & 2,91 & 2,23 & \\
\hline & Max. & 8,93 & 6,29 & 6,05 & 5,86 & \\
\hline \multirow{4}{*}{ Katalin } & Mean & 16,27 & 8,16 & 3,98 & 5,31 & $\mathbf{4 , 8 0}$ \\
\hline & Std. dev. & 5,84 & 1,70 & 0,74 & 0,90 & 1,00 \\
\hline & Min. & 6,10 & 5,49 & 2,12 & 3,47 & 2,08 \\
\hline & Max. & 23,56 & 12,77 & 5,72 & 8,03 & 6,50 \\
\hline \multirow{4}{*}{ Linda } & Mean & 5,90 & 4,48 & 3,76 & 3,69 & \\
\hline & Std. dev. & 1,40 & 0,93 & 1,19 & 0,79 & \\
\hline & Min. & 3,50 & 3,30 & 1,80 & 2,21 & \\
\hline & Max. & 8,85 & 6,81 & 8,00 & 5,89 & \\
\hline \multirow{4}{*}{ Stella } & Mean & 6,23 & 4,11 & 3,60 & 3,23 & \\
\hline & Std. dev. & 0,84 & 0,70 & 0,56 & 0,48 & \\
\hline & Min. & 4,71 & 3,11 & 2,72 & 2,35 & \\
\hline & Max. & 8,33 & 5,82 & 4,90 & 4,23 & \\
\hline \multirow{4}{*}{ Sunburst } & Mean & 10,93 & 5,48 & 4,67 & 4,12 & \\
\hline & Std. dev. & 2,44 & 1,39 & 1,05 & 0,91 & \\
\hline & Min. & 6,57 & 3,99 & 2,50 & 2,61 & \\
\hline & Max. & 16,62 & 8,25 & 6,35 & 6,70 & \\
\hline \multirow{4}{*}{ Vega } & Mean & 4,87 & 3,69 & 3,97 & 4,46 & \\
\hline & Std. dev. & 0,98 & 0,59 & 1,08 & 0,94 & \\
\hline & Min. & 2,81 & 2,87 & 0,81 & 2,41 & \\
\hline & Max. & 7,71 & 5,03 & 6,14 & 5,86 & \\
\hline
\end{tabular}

\section{Linda}

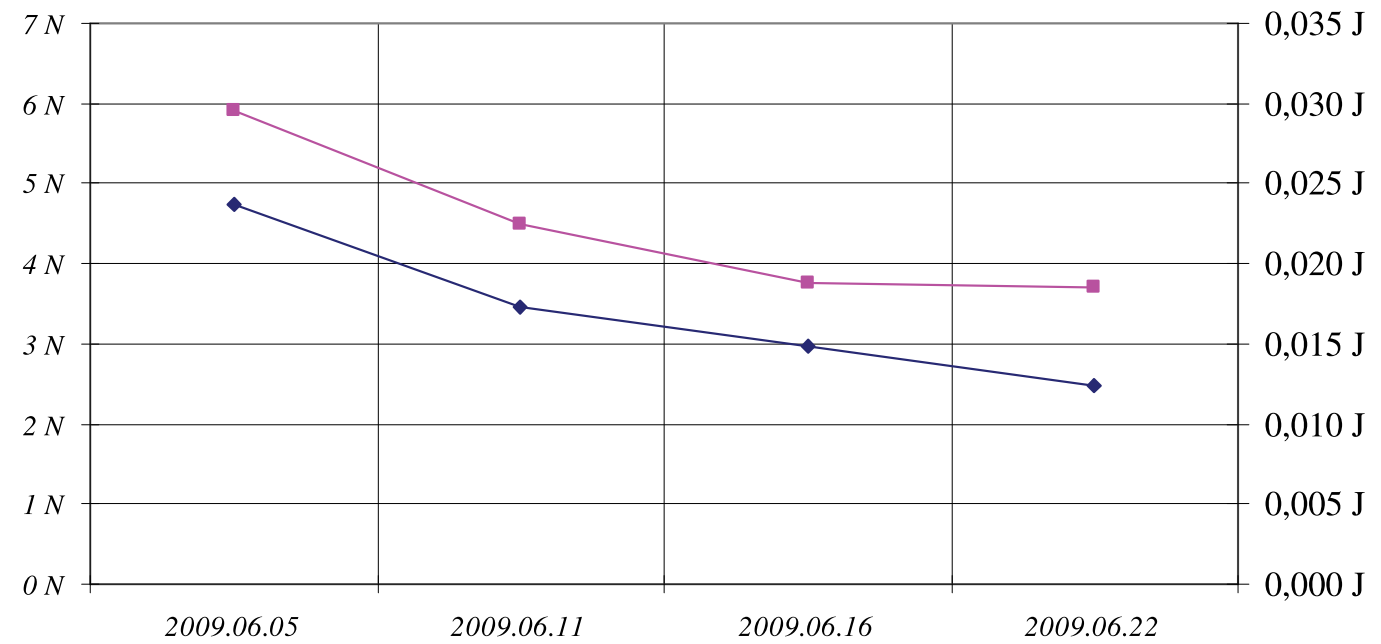

$\rightarrow$ Maximum Load $[\mathrm{N}] \quad \rightarrow$ Work to Break [J]

Figure 5. The maximal load and work to break in the function of time 
Table 5. The values of work to break

\begin{tabular}{|c|c|c|c|c|c|c|}
\hline \multirow{2}{*}{ Variety } & \multirow[b]{2}{*}{ Date } & \multicolumn{5}{|c|}{ Work to Break [J] } \\
\hline & & 2009.06 .05 & 2009.06 .11 & 2009.06 .16 & 2009.06 .22 & 2009.06 .30 \\
\hline \multirow{4}{*}{ Axel } & Mean & 0,0266 & 0,0179 & 0,0143 & 0,0092 & 0,0069 \\
\hline & Std. dev. & 0,0061 & 0,0067 & 0,0053 & 0,0033 & 0,0045 \\
\hline & Min. & 0,0133 & 0,0057 & 0,0051 & 0,0017 & 0,0024 \\
\hline & Max. & 0,0372 & 0,0289 & 0,0250 & 0,0172 & 0,0228 \\
\hline \multirow{4}{*}{ Blaze Star } & Mean & 0,0116 & & & & \\
\hline & Std. dev. & 0,0026 & & & & \\
\hline & Min. & 0,0053 & & & & \\
\hline & Max. & 0,0157 & & & & \\
\hline \multirow{4}{*}{ Cristallina } & Mean & 0,0228 & 0,0142 & 0,0106 & & \\
\hline & Std. dev. & 0,0047 & 0,0062 & 0,0037 & & \\
\hline & Min. & 0,0135 & 0,0047 & 0,0035 & & \\
\hline & Max. & 0,0321 & 0,0285 & 0,0178 & & \\
\hline \multirow{4}{*}{ Germersdorfi } & Mean & 0,0255 & 0,0228 & 0,0179 & 0,0148 & \\
\hline & Std. dev. & 0,0050 & 0,0037 & 0,0039 & 0,0036 & \\
\hline & Min. & 0,0182 & 0,0120 & 0,0116 & 0,0070 & \\
\hline & Max. & 0,0369 & 0,0298 & 0,0276 & 0,0198 & \\
\hline \multirow{4}{*}{ Katalin } & Mean & $\mathbf{0 , 0 3 3 5}$ & $\mathbf{0 , 0 3 2 7}$ & 0,0145 & 0,0187 & 0,0165 \\
\hline & Std. dev. & 0,0117 & 0,0095 & 0,0037 & 0,0052 & 0,0039 \\
\hline & Min. & 0,0116 & 0,0136 & 0,0069 & 0,0093 & 0,0061 \\
\hline & Max. & 0,0585 & 0,0501 & 0,0210 & 0,0328 & 0,0223 \\
\hline \multirow{4}{*}{ Linda } & Mean & $\mathbf{0 , 0 2 3 7}$ & 0,0174 & 0,0149 & 0,0124 & \\
\hline & Std. dev. & 0,0050 & 0,0056 & 0,0040 & 0,0025 & \\
\hline & Min. & 0,0122 & 0,0046 & 0,0071 & 0,0074 & \\
\hline & Max. & 0,0323 & 0,0241 & 0,0244 & 0,0182 & \\
\hline \multirow{4}{*}{ Stella } & Mean & 0,0331 & 0,0198 & 0,0181 & 0,0133 & \\
\hline & Std. dev. & 0,0050 & 0,0052 & 0,0036 & 0,0044 & \\
\hline & Min. & 0,0200 & 0,0081 & 0,0101 & 0,0042 & \\
\hline & Max. & 0,0426 & 0,0255 & 0,0289 & 0,0196 & \\
\hline \multirow{4}{*}{ Sunburst } & Mean & 0,0288 & 0,0190 & 0,0172 & 0,0133 & \\
\hline & Std. dev. & 0,0050 & 0,0052 & 0,0036 & 0,0032 & \\
\hline & Min. & 0,0202 & 0,0078 & 0,0072 & 0,0040 & \\
\hline & Max. & 0,0357 & 0,0302 & 0,0230 & 0,0177 & \\
\hline \multirow{4}{*}{ Vega } & Mean & 0,0210 & $\begin{array}{l}0,0100 \\
\end{array}$ & 0,0081 & 0,0077 & \\
\hline & Std. dev. & 0,0067 & 0,0066 & 0,0041 & 0,0030 & \\
\hline & Min. & 0,0048 & 0,0042 & 0,0008 & 0,0024 & \\
\hline & Max. & 0,0313 & 0,0398 & 0,0201 & 0,0161 & \\
\hline
\end{tabular}

In the process of mechanical harvesting of fruit the main task is to adjust the optimal shaking frequency and amplitude which results in efficient (at least 90\%) fruit detachment without causing damage in the bark of the tree or the fruit (Cooke \& Rand 1969).

The energy consumption of shaking is another important factor which is the function of the deflection and frequency.

The fruit-stem model (Figure 6.) shows the three main modes of movement of a sweet cherry hanging and oscillating on the stem. These are pendulum mode (left), tilting mode (centre) and twisting mode (right).
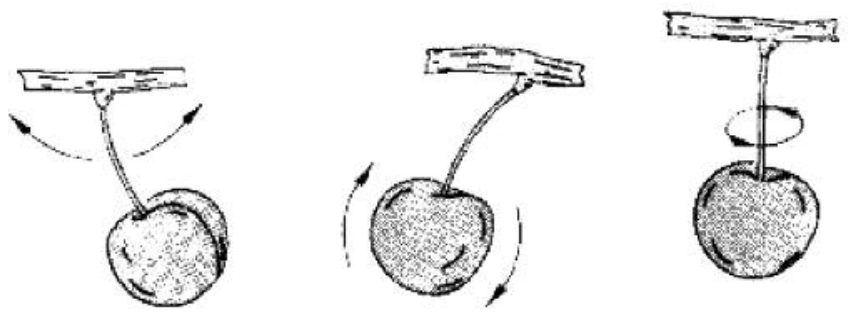

Figure 6. The three important modes of oscillation of the fruit (Cooke \& Rand 1969)
The fruit detachment mainly depends on the deflection of the limb which does not equal the deflection of the point of attachment of the tree. Due to the natural vibration damping effect of wood, especially the long, thin limbs transfer the shaking badly.

According to some laboratory tests the relation between the detachment force and detachment is not obvious (Sitkei 1981).

The work done during shaking expended on the detachment of fruit (Fekete et al. 2005). The value of this work for one circle:

$$
W=\delta m A^{2} \omega^{2}
$$

where:

$\delta$ - logarithmical decrement, vibration damping coefficient; $m$ - mass of the fruit;

$A$ - the deflection of the centre of mass;

$\omega-$ the frequency of deflection.

A fruit of $m$ mass joins to the branch with a stem of $l$ length, with $F$ static force.

The distance between the centre of mass of the fruit and the join is $(l+R)$. 
Multiplying the static detachment force $(F)$ with $(l+R)$, the virtual work will be given, which is needed to remove the fruit.

Dividing this work with the work done during shaking a number without a unit will be given:

$$
\Pi=\frac{F(l+R)}{m A^{2} \omega^{2}}
$$

The value of remains constant in the case of similar detachment processes.

The mathematical model of fruit shaking is shown in Figure 7 (Cooke\& Rand 1969):

It consists of a double compound pendulum with torsion springs. The upper torsion spring of sprig constant $S$ represents the lumped flexibility of the stem; the stem is represented by a thin, rigid rod of mass $\mu$ and length $L$. The lower torsion spring represents the lumped flexibility of the fruit-stem socket and have spring constant $K$ for the in-plane motion and spring constant $C$ for the twisting motion. The fruit is represented by a sphere of mass $M$ and radius $R$.

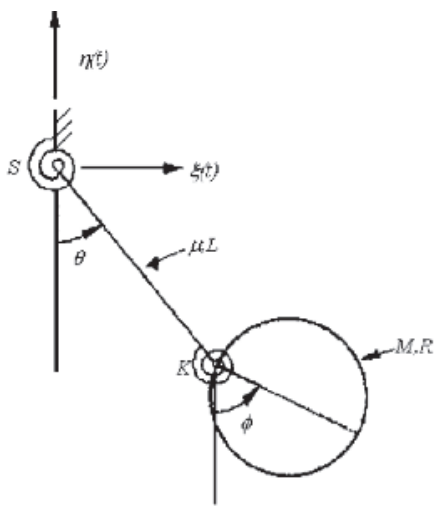

Figure 7. Mathematical model of fruit shaking (Cooke \& Rand 1969)

The three generalized co-ordinates are:

$\theta$ - the angle of deflection of the rod from the vertical;

$\varphi$ - the angle of deflection of the sphere from the vertical;

$\psi-$ the angle of twist of the sphere.

It is of interest to find the natural frequencies $(\omega)$ of this model. The potential energy is found to be:

$V=\frac{S \theta^{2}}{2}+\frac{K(\varphi-\theta)^{2}}{2}+\frac{C \psi^{2}}{2}-\frac{\mu g L \cos \theta}{2}-M g(L \cos \theta+R \cos \varphi)$

The kinetic energy may be written:

$T=\frac{\mu L^{2} \dot{\theta}^{2}}{6}+\frac{M\left[L^{2} \dot{\theta}^{2}+R^{2} \dot{\varphi}^{2}+2 R L \dot{\theta} \dot{\varphi} \cos (\theta-\varphi)\right]}{2}+\frac{M R^{2}\left(\dot{\varphi}^{2}+\dot{\psi}^{2}\right)}{5}$

After appropriate transformations of the equations the formula for the natural frequency of the model will be given for the twisting mode:

$$
\omega^{2}=\frac{5 C}{2 M R^{2}}
$$

According to deductions found in literature the following formula is true for the planar motions:

$$
\Omega=2 \omega
$$

This analysis indicates that the greatest dynamic instability of the fruit occurs at a shaking frequency of twice the natural frequency, when the upper end of the stem undergoes small, planar, elliptic displacements.

The work needed to detach the fruit has a great importance and it is generally true that it is decreasing during the ripening process.

The shaking parameters have to be adjusted carefully so that reduce bark and fruit damage.

There is a close connection between the necessary shaking time $(t)$ and the product of multiplication of frequency $(\omega)$ and amplitude $(A)$ :

$$
t\left[A \omega-(A \omega)_{c r}\right]=\text { const } .
$$

It is important to know the critical value of this product, because below this value there is no acceptable detachment even if we increase the shaking time.

The above expounded theoretical considerations have to be taken into consideration when we determine the optimal parameters of shaking.

\section{Reference}

Cooke, R. J. \& Rand, R. H. (1969): Vibratory Fruit Harvesting: A Linear Theory of Fruit-stem Dynamics. Agricultural Engineering Research, 14 (3): 195-209.

Fekete, A., Fenyvesi, L., Horváth, E. \& Sitkei, Gy. (ed. Sitkei, Gy.) (2005): Technological Relations of Fruit and Vegetable Production. (A gyümölcs- és zöldségtermesztés müszaki vonatkozásai) MGI könyvek, 4: 23-77.

Horváth, E.\& Sitkei, Gy. (2001): Energy Consumption of Selected Tree Shakers under Different Operational Conditions. Agricultural Engineering Research, 80 (2); 191-199.

Horvitz, S., Godoy, C., López Camelo, A. F. \& Yommi, A. (2002): http://www.inta.gov.ar/balcarce/info/documentos/agric/frutic/cherries. htm Hrotkó, K. (2003): Sweet Cherry and Sour Cherry. (Cseresznye és meggy). Mezőgazda Kiadó, Budapest, 12-13. 19-21. 4-60. 96-105.

Lenker, D. H. \& Hedden, S. L. (1968): Optimum Shaking Action for Citrus Fruit Harvesting. Transactions of the ASAE, 11 (3): 347-349.

Mateev, L. M. \& Kostadinov, G. D. (2004): Probabilistic Model of Fruit Removal during Vibratory Morello Harvesting. Biosystems Engineering, 87 (4); 425-435.

Papp, J. (2003): Fundamentals of Fruit Production. (Gyümölcstermesztési alapismeretek) Mezőgazda Kiadó, Budapest

Polyák, N.I. \& Csizmazia, Z. (2003): Phisical Properties of Seeds of Vegetables. Hungarian Agricultural Engineering. 16: 35-37.

Rand, R. H. \& Cooke, R. J. (1970): Vibratory Fruit Harvesting: A Non-linear Theory of Fruit-stem Dynamics. Agricultural Engineering Research., 15 (4): 347-363.

Sitkei, Gy. (1981): Mechanics of Agricultural Materials. (A mezőgazdasági anyagok mechanikája.) Akadémiai Kiadó, Budapest, 453

Soltész, M. (1998): Knowledge and Usage of Fruit Varieties. (Gyümölcsfajta-ismeret és használat Mezőgazda Kiadó, Budapest, 61-73.

Thurzó, S., Drén, G. \& Racskó, J. (2005a): A Comparative Examination of Free Fruitful and Fruit Quality of Sweet Cherry Varieties. (Cseresznyefajták szabadtermékenyülésének és gyümölcsminőségének összehasonlító vizsgálata.) Agrártudományi Közlemények, 16: 295-299.

Thurzó, S., Racskó, J., Dani, M., Drén, G., Holb, I.J., Soltész, M., Nyéki, J., Szabó, Z. (2005b): Virágyűrüség és terméskötődés cseresznye-fajták különböző hosszúságú termővesszőin. KertgazdaságKülönszám: A fajtaválaszték fejlesztése a kertészetben (szerk: Tóth M.): 79-82. 